\title{
Schmitt, T. (2020). Juegos filarmónicos (T. Schmitt, guitarra de seis órdenes) [CD]. Lindoro, NL 3044. 2019.
}

El nuevo CD del profesor de la Universidad de La Rioja y destacado investigador Thomas Schmitt, Juegos filarmónicos, constituye una sobresaliente aportación a la recuperación y difusión del repertorio guitarrístico; recopila música de finales del siglo XVIII, probablemente menos conocida hoy en día que la música posterior (basta pensar en las abundantes grabaciones de la obra de Fernando Sor), lo que no significa que aquella poseyera menos calidad. Ha sido editado por el conocido y prestigioso sello discográfico Lindoro (NL-3044), especializado en música antigua española y en cuya producción ya han aparecido en los últimos años un buen número de interesantes aportaciones discográficas.

En el CD de Schmitt suenan obras de autores como Isidoro de Laporta, Manuel Ferau, Antonio Abreu, José Avellana, Juan Antonio de Vargas y Guzmán o Antonio Nava, es decir, compositores y guitarristas que desgraciadamente no forman parte del canon guitarrístico, pero que en su momento estuvieron muy presentes en la vida musical de finales del XVIII y principios del XIX, gozando de predicamento artístico.

Todas las piezas grabadas proceden de archivos españoles, lo que demuestra una vez más la riqueza que existe en nuestro patrimonio musical y que todavía resta por recuperar, por lo que deben saludarse grabaciones de esta naturaleza que dan a conocer repertorios inéditos de gran valor.

Por cierto, el título Juegos filarmónicos procede de un $V$ als de Antonio Nave que se genera mediante dados. Es, en este sentido, una composición aleatoria que juega con la combinación de compases.

Se puede percibir que Thomas Schmitt es tanto guitarrista como musicólogo, pues el libreto, a cargo del propio intérprete, es muy recomendable por su elevado interés musicológico: ofrece una visión general de aquella época desde la perspectiva de la historia social, unas décadas en las que la música era considerada una mercancía, como cualquier otro producto. El texto revela detalles interesantes sobre los precios de los productos en relación con la música y nos hace ver que la música de aquel tiempo ya podría considerarse elitista. El libreto, incluye también unas atrayentes reflexiones sobre "las repeticiones de los movimientos", en las que Schmitt analiza pormenorizadamente el nuevo concepto del tiempo que surge a finales del siglo XVIII y que repercute en la construcción de los movimientos musicales. 
Sobre la interpretación de las piezas con una guitarra de 6 órdenes (construida por Carlos Gass según un modelo de 1792), puede decirse que se caracteriza por su certeza estilística, su pulcritud en la ejecución y una flexible y diversificada sonoridad, en la línea de las grabaciones anteriores de Thomas Schmitt, plenas de originalidad y capaces de ofrecernos un discurso musical novedoso y muy personal. De hecho, se considera a este guitarrista como uno de los máximos especialistas y conocedores de este tipo de repertorio histórico.

En resumidas cuentas, otro excelente trabajo musicológico y de interpretación por parte de Thomas Schmitt, que nos hace comprender de manera muy convincente un repertorio guitarrístico aún por descubrir.

\section{Paulino Capdepón Verdú}

Universidad de Castilla-La Mancha Centro de Investigación y Documentación Musical (CIDoM)-Unidad Asociada al CSIC ORCID iD: https://orcid.org/0000-0001-6509-3496 